\title{
The Effect of PBL and 21st Century Skills on Students' Creativity and Competitiveness in Private Schools
}

\author{
Amina Talat ${ }^{*}$ and Hina Fakhar Chaudhry
}

\begin{abstract}
In an environment of slow economic growth where many businesses have failed, one sector that has done exceedingly well is the private education business. This study examines the effect of project-based learning (PBL) and 21st century skills on students' creativity and competitiveness in private schools in Lahore. Today, enhancing 21st century skills to make students more competitive in an external environment is key to education systems around the world. The PBL framework also supports children's social and personal development. We have used primary research methods to survey teachers at a range of private schools. The results show that 21st century skills embedded in the PBL framework have a positive impact on students' creativity and competitiveness. Social development influences creativity and competitiveness the most while personal development is the least influential factor.
\end{abstract}

Keywords: PBL, 21st century skills, communication, collaboration, critical thinking, student creativity, student competitiveness, social development, personal development.

JEL classification: M10, M19, M29.

\section{Introduction}

The private sector has played an important role in the education sector in Pakistan. Following the Bhutto government's nationalization drive in the 1970s, the public school system broke down. The sector faced numerous problems, including insufficient funds, inefficient program implementation, and poor-quality management and teaching (Memon, 2007). This situation created a lucrative business opportunity for the private sector. The 1970s and 1980s saw many school systems mushroom across the country, notably the Beaconhouse School System, the City School, the Lahore University of Management Sciences, the Punjab Colleges Group, and the Roots School System (Dar, 2012).

\footnotetext{
${ }^{*}$ The author is an assistant professor at the Lahore School of Economics.
} 
Rapid social and technological development in today's knowledge society has changed the dynamics of the working environment, the structure of educational institutions, and ways of collaboration. This requires students to develop new skills to successfully face such challenges. Bondelli (2007) argues that traditional educational systems relied wholly on intellectual learning and excluded experiential learning, which allows students to explore and learn by doing (e.g., a child who sows a seed and observes how it grows learns to identify the life cycle of the plant).

Supporting the philosophy of 'learning by doing' is the Reggio Emilia approach (Hewett, 2001), which holds that children have control over their learning path: they learn and express themselves through touch, movement, observation, and sound. This approach has been adopted by many educational institutions worldwide under the unique program of project-based learning (PBL). PBL encompasses performance-based assessment, the classroom environment, and a student-driven-teacherfacilitated learning relationship. Bell (2010) describes PBL students as those that drive their own lines of inquiry, work collaboratively to seek viable solutions using advanced technology, and communicate their findings to the relevant audience.

Today, enhancing 21st century skills to make students more competitive in an external environment is key to education systems around the world. The concept of 21st century skills is not new, but the practice of explicitly aligning these skills with the designed curricula and education policies is relatively recent. Critical thinking skills are highlighted in particular as an end per se to gain the desired educational and employment outcomes identified by Miller, Sadler, and Mohl (1993). To prepare their pupils for work and life in the 21st century, educators must cultivate their creativity and align assessment with learning outcomes. Moreover, while technology is often emphasized as a 21st century teaching aid, it should not be at the expense of the social and behavioral aspects on which $21^{\text {st }}$ century professional skills are based.

\section{Research Objectives}

Given that the literature highlights the significance of PBL and 21st century skills in terms of the three C's of communication, collaboration, and critical thinking, our study has the following aims:

- To ascertain the relationship between PBL and 21st century skills 
- To measure the mediating effect of 21st century skills on students' creativity and competitiveness

- To explore the effect of PBL on children's personal and social development

- To determine how this personal and social development enhances children's creativity and competitiveness.

\section{Literature Review}

The rapid social and technological development of the knowledgebased society has changed the way education is addressed and viewed. In generic terms, it is often referred to as the transmission of knowledge. Traditional education systems were limited to a few selected fields that were taught according to a set curriculum and textbooks. This system has now been replaced by modern, liberal education, which caters to individual needs, interests, and capabilities. Students are exposed to experimental learning that allows them to explore and learn by doing.

The concept of experimental learning is not new. The Reggio Emilia approach developed by Loris Malaguzzi in the 1940s in Italy was one of the earliest education techniques of learning by doing: it differed from the prevailing systems, which tended to dampen creativity and critical thinking. The Reggio Emilia approach holds that children communicate ideas through symbols, words, pictures, music, and drama, which enhance their creativity and conceptual clarity (Edwards \& Springate, 1993).

Inspired by Malaguzzi's poem "The child has a hundred languages, and a hundred-hundred-hundred more," these multiple forms of illustration and representation became famous as the "hundred languages of children." The approach also supported the importance of an interrelationship between parents and teachers, the environment, and other related fields facilitating students in the learning process. Studies such as Edwards, Gandini, and Forman (1998), Katz (1990), and Malaguzzi (1993) support the Reggio Emilia philosophy as an approach that focuses on the importance of relationships in a child's learning process (Kocher, 2013).

The PBL approach values student choice and aligns 21st century skills with learning-by-doing (Bell, 2010). The setup and environment of PBL classrooms encourage students to think critically, contribute to team efforts, and work creatively when confronted with a new challenge (Boss, 2012). Such a setup not only provides the opportunity to explore extensively 
but also helps students identify constraints they might face in real-life situations and develop the skills they will need to address these. Some educators have, however, questioned whether such assessment techniques support scores and ensure that a student's performance is reliable enough to justify high-stakes decisions pertaining to his or her future in a system still dominated by traditional evaluation and appraisal methods.

Originally applied in medical schools, PBL provides students the opportunity to learn by conducting in-depth inquiry and applying critical thinking skills in order to solve the problem at hand. PBL practices vary by grade and allow students to exercise choice. The approach also connects curricula to 21st century skills (communication, collaboration, and critical thinking (Ravitz, Hixson, English, \& Mergendoller, 2012).

The Harvard Business Review defines the set of 21st century skills as the ability to "compete on analytics." In general, these skills incorporate the principal proficiencies of communication, collaboration, and critical thinking. Barnett Berry, founder of the Center for Teaching Quality, describes these skills as a combination of the three C's of creativity, communication, and collaboration.

Teaching that facilitates these skills aims to prepare pupils to solve real-life problems by mastering content while constructing, integrating, and gauging information from a range of subjects and sources with an understanding of and veneration for diverse cultures. Partnership for 21st Century Skills (2007) indicates a 99 percent universal agreement that teaching these skills is imperative for a country's economic prosperity.

Several frameworks have been developed to explore the set of 21st century skills. Of these skills, critical thinking that encompasses real-world problem solving is a key driver of high work quality (Microsoft Partners in Learning, Pearson Foundation, \& Gallup, 2013). Assessment and Teaching of 21st Century Skills (ATC21S) (2010) describes critical thinking as "ways of thinking" that lead to creativity and innovation when making a decision or solving a problem. One of the earliest definitions developed by Ennis (1985) defines critical thinking as "thinking reflectively and reasonably in order to plan actions and decisions accordingly."

Collaboration and communication are synonymously depicted as "ways of working" under the ATC21S framework. Collaboration is seen as a key outcome of teaching strategies and methodologies, and refers to the ability to coordinate with one's peers in constructing viable solutions to a 
problem (Roshchelle \& Teasley, 1995). Specifically, collaboration is the process of "joint problem-solving" (Dillenbourg, 1999). However, effective interpretation and collaboration require one to be able to communicate information and ideas clearly. Effective communication also lays the groundwork for professional success and can entail using verbal and nonverbal means (Trilling \& Fadel, 2009).

The literature highlights the importance of 21st century skills in nurturing creativity and competitiveness among students; how these skills are imparted is equally significant. Their constructs can be gauged by integrating several measures, such as designing complex tasks, setting open-ended problems, making student thinking and reasoning visible, and adopting innovative approaches that employ new technology and models (Lai \& Viering, 2012).

Within the PBL framework, creativity and competitiveness are key to success. Creativity is the ability to innovate and helps prepare pupils for future challenges in work and life. As per the framework developed by the National Research Council, creativity is described as "cognitive nonroutine problem solving" (Lai \& Viering, 2012). Robert Epstein at the University of California, San Diego, outlines four proficiencies crucial for creative expression:

- Capturing: developing new ideas

- Challenging: giving students stimulating problems to solve

- Broadening: increasing creativity by learning interesting facts and figures

- Surrounding: relating to interesting and diverse concepts and culture

Epstein argues that "capturing" is the most important proficiency and suggests that teachers should focus on it daily in order to encourage pupils to generate ideas (Henderson, 2008). Creativity should not be confined to a subject or curriculum boundaries; rather, it should be directed at finding viable solutions to a given problem as in PBL. This, in turn, will help equip students to solve problems both in their personal and work lives.

There are four main skill areas that affect creativity and innovation: (i) fluency, (ii) flexibility, (iii) elaboration, and (iv) originality (Torrance, 1981). By embedding creative, purposeful tasks into teaching programs, schools can help equip students with the primary tools of thinking and the 
will to create. Creativity is also an important part of the liberal arts, academic values, and higher-order thinking skills (Angelo \& Cross, 1993).

Being creative and performing well on international assessments, however, does not provide a complete picture. It is imperative that educationists should focus on how students will apply the knowledge they have acquired to real-world settings. This calls for competitive skills, which consist of basic academic success skills and discipline (specific knowledge and skills) (Angelo \& Cross, 1993).

PBL is also found to support children's personal and social development by enhancing their managerial and leadership skills and by preparing them to implement complex skills such as planning, communicating, problem-solving, and decision-making. Increased selfreliance and the ability to work in a social environment make individuals more competitive and creative (Pekrun, Goetz, Titz, \& Perry, 2002).

Developed economies, industries, and high-growth jobs require a competitive workforce that can communicate effectively, manage information, work in teams, and seek viable solutions to a problem. Accordingly, the education sector needs to impart 21st century skills that drive participation, accomplishment, and competitiveness in the global economy (Fincher et al., 2000). Modern businesses require human capital that helps build a knowledgeable and competitive workforce (Gayl, 2007). To be productive workers in a rapidly changing and increasingly competitive economy, individuals will need those skills and competencies that help them make effective, operative, and innovative use of what they have learned at school and work.

\section{Theoretical Framework}

Based on the PBL framework developed in Section 3, we aim to determine the effect of PBL and 21st century skills in private sector schools in Lahore. There has been very limited work carried out in this domain and many schools still adopt a rigid education system that focuses on the scores and grades achieved. PBL plays a role in imparting 21st century skills and in students' personal and social development, which, in turn, affect their creativity and competitiveness. Accordingly, in this study, creativity and competitiveness are the dependent variables, 21st century skills and social and personal development are the mediating variables, and PBL is the independent variable (see Figure 1). 
Sprinthall and Sprinthall (1977) argue that personal development between the ages of 12 and 18 involves the ability to differentiate one's feelings from those of others. This allows one to accept and understand the viewpoint of other people and role-play when solving problems similar to real-life situations (Erikson, 1980). We will ascertain the impact of PBL on personal development as it helps children develop relationships by collaborating with peers and third parties and making decisions as part of a team. PBL also helps cultivate one's self-confidence and builds the capacity to take responsibility.

Following Combs and Slaby (1977), social development is defined as the ability to interact with others in a given social context in ways that are socially acceptable or valued and, at the same time, are personally or mutually beneficial or beneficial primarily for the other (Linke, 2009). The social penetration theory (Altman \& Taylor, 1973) states that interpersonal relationships proceed on the basis of communication. Thus, in order to build social relationships, one needs to share one's thoughts with others. We aim to determine the impact of PBL on social development by measuring the constructs of work and career preparation that define it. Social development, in turn, enhances individual creativity and competitiveness in external environments.

Fogarty (2013) describes creativity as the "ideation of a thought." We expect 21st century skills to have a positive impact on student creativity, which, for our purposes, is measured by the constructs liberal arts and academic values, and higher-order thinking skills (Angelo \& Cross, 1993).

Gayl (2007) defines competitiveness as the ability to apply one's acquired knowledge to real-world settings in order to develop effective solutions to given problems. Cultivating 21st century skills is imperative to producing a competitive individual. We measure student competitiveness by the constructs basic academic success skills and discipline-specific knowledge and skills (Angelo \& Cross, 1993). 
Figure 1: Relationship between study variables

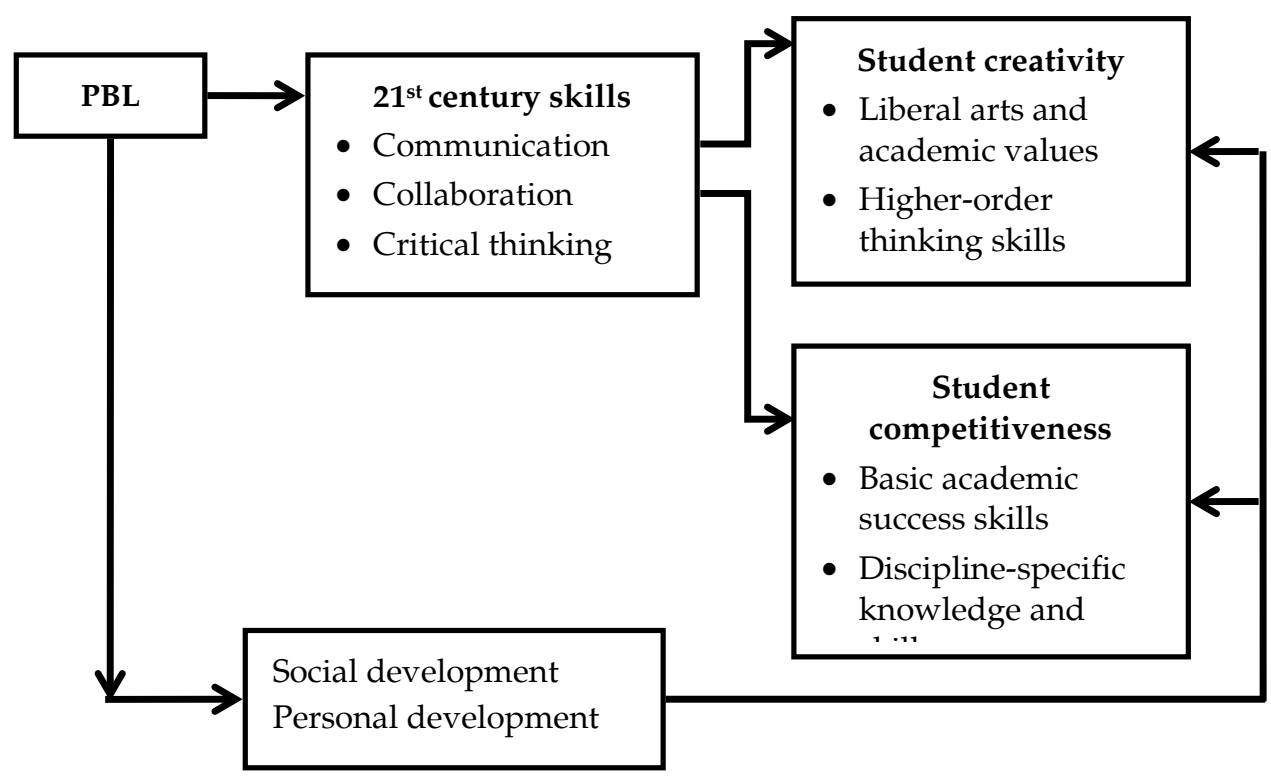

\section{Hypotheses}

We present the following hypotheses:

- H1: The existence of PBL supports 21st century skills.

- H2: 21st century skills are positively related to student creativity.

- H3: 21st century skills are positively related to student competitiveness.

- H4: PBL supports student social development.

- H5: PBL supports student personal development.

- H6: Social development is positively associated with student creativity.

- H7: Social development is positively associated with student competitiveness.

- H8: Personal development is positively associated with student creativity.

- H9: Personal development is positively associated with student competitiveness. 


\section{Methodology}

The study population comprised teachers working at elementary, primary, and middle private schools in Lahore. The sample included 30 teachers from each of the five private schools selected on a voluntary basis (see Table A1 in the Appendix). In the survey questionnaire used, PBL was measured as "practicing PBL and supporting 21st century skills" or "not practicing PBL or supporting 21st century skills" (see Ananiadou \& Claro, 2009). The survey was carried out at the school level rather than country level. The following sections describe the instruments used.

\subsection{New Millennium Learners Country Survey}

The New Millennium Learners (NML) country survey was prepared and administered by Ananiadou and Claro in 2009. The purpose of the survey was to collect data on whether and how schools in OECD countries taught and assessed 21st century skills through their curricula and policy guidelines, how these skills were defined and assessed, and what impact they had on teacher training programs. These objectives also apply to our study. The survey uses yes/no options and certain openended questions. For our purposes, the selected items indicate the presence of PBL supporting 21st century skills in the five respondent schools.

\subsection{Teaching Goals Inventory}

The Teaching Goals Inventory questionnaire, which was used by the Middle State Commission on Higher Education in 2007, is a selfassessment tool through which teachers respond to instructional goals. For our study, the instrument was used to measure 21st century skills, student creativity, competitiveness, and social and personal development within the framework of several constructs. The instrument includes 52 items measured on a 1-5 rating scale (see Appendix). Overall, a total of 150 questionnaires were administered, of which 100 were later used to input data, resulting in a response rate of 66.67 percent.

\section{Findings and Analysis}

This section presents a qualitative, reliability, and path analysis.

\subsection{Qualitative Analysis}

The results of the NML questionnaire showed that all the selected schools applied PBL in their academic environments but in different ways. 
Some were implementing PBL in the context of International Baccalaureate procedures and guidelines while others were imparting 21st century skills in the form of projects per theme. Figure 2 shows the percent of schools that reported covering key skills and competencies as part of their policies and assessment criteria.

Figure 2: Respondents covering key PBL skills

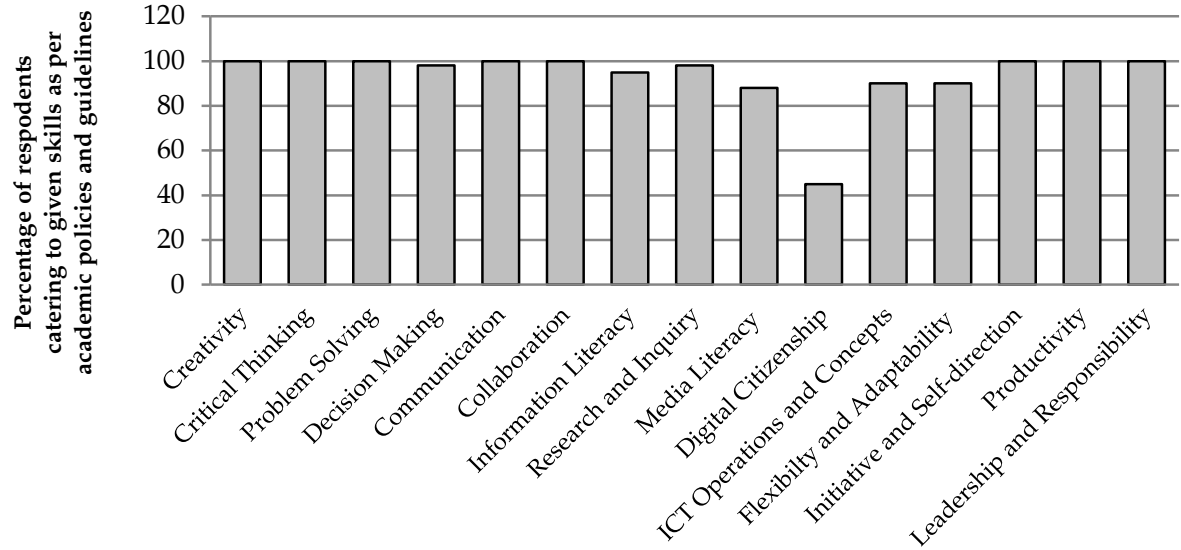

Skills/Competencies

Respondents also reported that, under the PBL umbrella, their educational policies and teaching goals incorporated social and personal development in the shape of skills inculcating leadership, responsibility, collaboration, initiative, and self-direction. Based on these qualitative findings, we can deduce that PBL supports the 21st century skills framework adopted by these schools and contributes to students' social and personal development.

\subsection{Reliability Analysis}

Reliability measures the stability of outcomes when the purpose of the research is measured repeatedly. The reliability of data related to latent variables and operational constructs was measured using Cronbach's alpha methodology. As Table 1 shows, the Cronbach's alpha values for data on all five variables/constructs is above the threshold value of 0.70 , which complies with the reliability criterion. 
Table 1: Reliability of data

\begin{tabular}{lc}
\hline Scale & Cronbach's Alpha \\
\hline Social development & 0.95 \\
21st century skills & 0.89 \\
Personal development & 0.72 \\
Student creativity & 0.95 \\
Student competitiveness & 0.97 \\
\hline
\end{tabular}

We also run a confirmatory factor analysis (CFA) to gauge whether the proposed model is a good fit and to measure the correlations between the designated variables (see Figure 3). Table 2 shows that the suggested model is a good fit and can be used in future studies. The value of the CMIN/DF (1.329) is below 3, suggesting a good fit. The comparative fit index (CFI) analyzes model fit by examining the discrepancy between the data and the hypothesized model while adjusting for the issue of sample size inherent in the chi-squared test of model fit and the normed fit index. The CFI value for the model is 0.915 , indicating an acceptable model fit.

Table 2: Model fit summary

\begin{tabular}{lccccccc}
\hline & CMIN/DF & P & GFI & AGFI & CFI & TLI & RMSEA \\
Default model & 1.329 & 0 & 0.664 & 0.634 & 0.915 & 0.911 & 0.058 \\
\hline
\end{tabular}

The root mean square error of approximation (RMSEA) avoids issues of sample size by analyzing the discrepancy between the hypothesized model-using optimally chosen parameter estimates-and the population covariance matrix. The RMSEA value for the model is 0.058 , which is below the threshold value of 0.10 and thus lies within the acceptable range. The value of the goodness of fit index (GFI) is lower because of its sensitivity to a large number of items associated with the variables. This value could be improved in future studies by standardizing and developing another measuring scale with fewer items.

We find that significant relationships exist between the constructs. The model suggests that 21st century skills have an impact on student creativity and competitiveness. There is also a significant correlation between social and personal development and student creativity and competitiveness. The CFA indicates that academic tasks and curricula designed around the PBL approach support the framework of 21st century skills and enhance creativity and competitiveness when students are 
exposed to real-life problems: they are encouraged to think critically and carry out in-depth inquiries to seek possible solutions. During this learning process, students not only develop higher-order thinking skills but also enhance their capacity to communicate and collaborate.

Figure 3: Confirmatory factor analysis

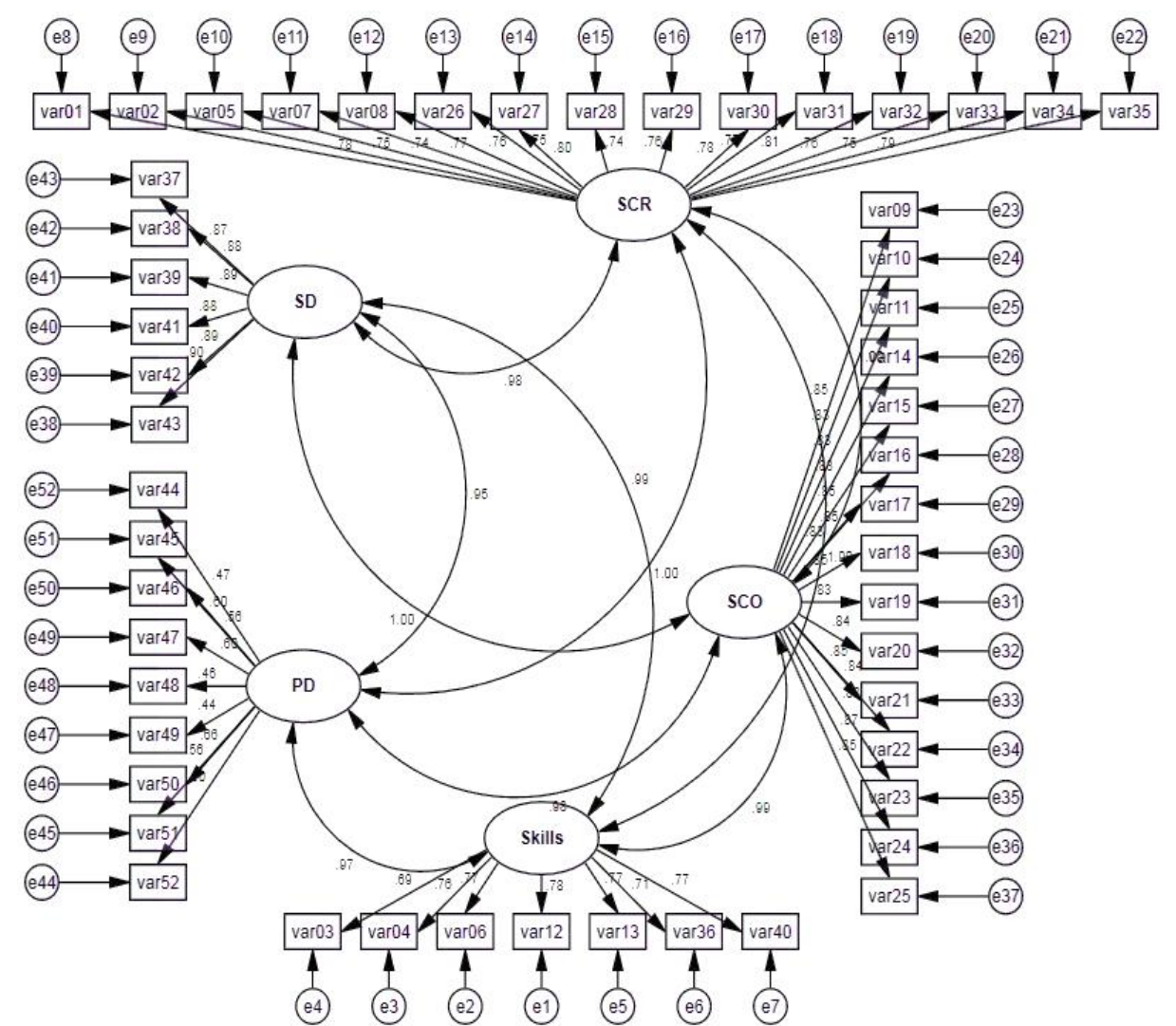

\subsection{Path Analysis}

Path analysis is a statistical technique used to test and estimate causal relationships. The value of CMIN/DF (1.567) is below 3, suggesting a good fit. The CFI value is 0.853 , indicating an acceptable model fit. The RMSEA value is 0.076 , which is below the threshold value of 0.10 and thus lies within the acceptable range. 
Table 3: Model fit summary

\begin{tabular}{llllllll}
\hline & CMIN/DF & P & GFI & AGFI & CFI & TLI & RMSEA \\
Default model & 1.567 & 0 & 0.641 & 0.61 & 0.853 & 0.846 & 0.076 \\
\hline
\end{tabular}

Our hypotheses are confirmed as follows:

- H1: There is a significant and positive relationship between PBL and 21st century skills. The beta value of 0.56 is significant at a 0.05 level of significance. This implies that PBL supports the 21st century skills framework; 21st century skills thus mediate the effect of PBL on student creativity and competitiveness. This allows us to accept H1.

- H2: The relationship between 21st century skills and student creativity is significant at a 0.05 level with a regression weight of 0.583 . This indicates a positive relationship between the two variables and allows us to accept $\mathrm{H} 2$.

- H3: The relationship between 21st century skills and student competitiveness is significant at a 0.05 level with a regression weight of 0.334 . This indicates a positive, if weak, relationship between the two variables, and allows us to accept $\mathrm{H} 3$.

- H4: The relationship between PBL and social development is significant at a 0.05 level with a regression weight of 0.325 . This indicates a positive, if weak, relationship between the two variables, and allows us to accept $\mathrm{H} 4$.

- H5: The relationship between PBL and social development is significant at a 0.05 level with a regression weight of 0.412 . This indicates a positive, if weak, relationship between the two variables, and allows us to accept $\mathrm{H} 5$.

- H6: The relationship between social development and student creativity is significant at a 0.01 level with a regression weight of 0.715. This indicates a strong positive relationship between the two variables, and allows us to accept $\mathrm{H} 6$.

- H7: The relationship between social development and student competitiveness is significant at a 0.01 level with a regression weight of 0.911 . This indicates the strongest positive relationship compared to all the other variables, and allows us to accept H7.

- H8: The relationship between personal development and student creativity is significant at a 0.05 level with a standardized regression weight of 0.406 . This indicates a moderate and positive relationship 
between the two variables. When personal development rises by 1 standard deviation, student creativity increases by 0.406 standard deviations. This allows us to accept $\mathrm{H} 8$.

- H9: The relationship between personal development and student competitiveness is significant at the two-tailed level with a standardized regression weight of 0.250 . This indicates the weakest but positive relationship compared to all the other variables, and allows us to accept $\mathrm{H} 9$.

Social development exhibits the strongest relationships with student creativity and competitiveness (with regression weights of 0.71 and 0.91, respectively). This is an important finding, given that most other studies have focused on 21st century skills as the major influencing factor. Personal development, on the other hand, shows the weakest correlation.

\section{Conclusion and Managerial Implications}

We have found that PBL supports the 21st century skills framework along with personal and social development. 21st century skills influence student creativity more than they do student competitiveness. The study's key finding is that social development is the strongest influencing factor on creativity and competitiveness. Personal development, on the other hand, has a weak but positive impact on the dependent variables.

The study has several important implications for educationists who wish to initiate successful, modern, and challenging academic practices within the education environment and system. The PBL approach relates to modern skills and competencies that are required to make students more competitive. Students are encouraged to undergo an extended process of inquiry in response to a complex problem. While allowing for some degree of student "voice and choice," rigorous projects are carefully planned, managed, and assessed to help students learn key academic content, practice 21st century skills (such as collaboration, communication, and critical thinking), and create high-quality, authentic products.

The study provides theoretical as well as quantitative evidence of how the PBL approach has overtaken the traditional education system and why it is imperative for children's learning process. Educationists and education policymakers should understand the implications of PBL and update their teaching goals and policies in line with the constructs of 21st century skills and social development in order to achieve a better and more challenging education system. 
Given that our study was limited to selected private schools in Lahore, the results do not estimate the presence and impact of PBL and 21st century skills on the overall education system of Pakistan. Moreover, the variables assigned to measure the given constructs were chosen subjectively based on the literature and on other instruments that might not be representative of the exact nature of the study.

Social development emerges as the strongest influential factor, which provides a new path for future research. Additionally, since PBL was measured in terms of "practicing" or "not practicing", future research could aim to develop constructs that measure PBL itself. 


\section{References}

Altman, I., \& Taylor, D. A. (1973). Social penetration: The development of interpersonal relationships. New York, NY: Holt, Rinehart \& Winston.

Ananiadou, K., \& Claro, M. (2009). 21st century skills and competences for new millennium learners in OECD countries (OECD Education Working Paper No. 41). Paris, France: OECD Publishing.

Angelo, T., \& Cross, K. P. (1993). Classroom assessment techniques: A handbook for college teachers. San Francisco, CA: Jossey Bass.

Assessment and Teaching of 21st Century Skills. (2010). Status report as of January 2010. Melbourne, Australia: Author. Retrieved from http:/ /atc21s.org/wpcontent/uploads/2011/04/January2010StatusReport.pdf

Bell, S. (2010). Project-based learning for the 21st century: Skills for the future. The Clearing House, 83(2), 39-43.

Bondelli, K. J. (2007). An evaluation of the ineffectiveness of the traditional educational system (Mimeo). Retrieved from http:// scribd.com/doc/38418/An-Evaluation-of-the-TraditionalEducation-System-by-Kevin-Bondelli

Boss, S. (2012, May). How project-based learning builds 21st century skills [Weblog]. Retrieved from http://www.edutopia.org/blog/21stcentury-skills-pbl-suzie-boss

Combs, M. L., \& Slaby, D. A. (1977). Social skills training with children. In B. B. Lahey \& A. E. Kazdin (Eds.), Advances in clinical child psychology (pp. 161-201). New York, NY: Springer.

Dar, H. (2012). Private schools: Quality of education in Pakistan. Express Tribune, 24 June. Retrieved from http:/ / tribune.com.pk/story/398535/private-schools--quality-ofeducation-in-pakistan/

Dillenbourg, P. (Ed.) (1999). Collaborative learning: Cognitive and computational approaches. Oxford, UK: Elsevier. 
Edwards, C. P., Gandini, L., \& Forman, G. E. (Eds.). (1998). The hundred languages of children: The Reggio Emilia approach - Advanced reflections. Westport, CT: Greenwood Publishing Group.

Edwards, C., \& Springate, K. (1993). Inviting children into project work. Dimensions of Early Childhood, 40, 9-12.

Ennis, R. H. (1985). A logical basis for measuring critical thinking skills. Educational Leadership, 43(2), 44-48.

Erikson, E. H. (1980). Identity and the life cycle (vol. 1). New York, NY: WW Norton.

Fincher, R. M. E., Simpson, D. E., Mennin, S. P., Rosenfeld, G. C., Rothman, ... \& Turnbull, J. M. (2000). Scholarship in teaching: an imperative for the 21st century. Academic Medicine, 75(9), 887-894.

Fogarty, R. (2013, February). Creativity: The premier skill of the 21st century [Web page]. Retrieved from http://www.p21.org/tools-andresources/p21blog/1118-robin-fogarty-creativity

Gayl, L. C. (2007). Global competitiveness in the 21st century (Policy research brief). Alexandria, VA: National School Boards Association.

Goodnight, J. (2011). Educating for global competitiveness (White paper). Cary, NC: SAS Institute.

Henderson, J. (2008). Developing students' creative skills for 21st century success. Education Update, 50(12). Retrieved from http://www.ascd.org/publications/newsletters/educationupdate/dec08/vol50/num12/Developing-Students'-CreativeSkills-for-21st-Century-Success.aspx.

Hewett, V. M. (2001). Examining the Reggio Emilia approach to early childhood education. Early Childhood Education Journal, 29(2), 95-10.

Katz, M. B. (1990). The undeserving poor: From the war on poverty to the war on welfare. New York, NY: Pantheon Books.

Kocher, L. (2013). Research into practice: Reggio Emilia (Research into Practice Series, vol. 4). Vancouver, BC: Institute for Early Childhood Education. Retrieved from http:/ / earlychildhood.educ.ubc.ca/community/researchpractice-reggio-emilia 
Lai, E. R., \& Viering M. (2012). Assessing 21st century skills: Integrating research findings. Vancouver, BC: National Council on Measurement in Education. Retrieved from http://www.pearsonassessments.com/hai/images/tmrs/Assessi ng_21st_Century_Skills_NCME.pdf

Linke, P. (2009). Social development of children. Presentation made to the Government of South Australia, Child and Family Health Division. Retrieved from http://www.adelaide.edu.au/hda/news/Linke.pdf

Malaguzzi, L. (1993). For an education based on relationships. Young Children, 49(1), 9-12.

Memon, G. R. (2007). Education in Pakistan: The key issues, problems and the new challenges. Journal of Management and Social Sciences, 3(1), $47-55$.

Microsoft Partners in Learning, Pearson Foundation, and Gallup. (2013). 21st century skills and the workplace. Washington, DC: Gallup. Retrieved from http://www.gallup.com/strategicconsulting/162821/21stcentury-skills-workplace.aspx

Miller, D. A., Sadler, J. Z., \& Mohl, P. C. (1993). Critical thinking in preclinical course examinations. Academic Medicine, 68(4), 303-305.

Pacific Policy Research Center. (2010). 21st century skills for students and teachers. Honolulu, HI: Kamehameha Schools, Research and Evaluation Division. Retrieved from http://www.ksbe.edu/spi/PDFS/21 century skills full.pdf

Partnership for 21st Century Skills. (2007). Beyond the three Rs: Voter attitudes toward 21st century skills. Tucson, AZ: Author. Retrieved from http://www.p21.org/storage/documents/p21_pollreport_2pg.pdf

Pekrun, R., Goetz, T., Titz, W., \& Perry, R. P. (2002). Academic emotions in students' self-regulated learning and achievement: A program of qualitative and quantitative research. Educational Psychologist, 37(2), 91-105.

Ravitz, J., Hixson, N., English, M., \& Mergendoller, J. (2012, April). Using project-based learning to teach 21st century skills. Paper presented at 
the annual meeting of the American Educational Research Association, Vancouver, BC.

Roschelle, J., \& Teasley, S. D. (1995). The construction of shared knowledge in collaborative problem solving. In C. O'Malley (Ed.), Computer-supported collaborative learning (pp. 69-97). Berlin: Springer-Verlag.

Sprinthall, R. C., \& Sprinthall, N. A. (1977). Educational psychology: A developmental approach. Reading, MA: Addison-Wesley.

Torrance, E. P. (1981). Predicting the creativity of elementary school children (1958-80) - and the teacher who "made a difference". Gifted Child Quarterly, 25(2), 55-62.

Trilling, B., \& Fadel, C. (2009). 21 st century skills: Learning for life in our times. San Francisco, CA: Jossey Bass. 


\section{Appendix}

Table A1: Respondents' demographic characteristics

\begin{tabular}{|c|c|c|c|c|c|}
\hline & & Frequency & Percent & $\begin{array}{c}\text { Valid } \\
\text { percent }\end{array}$ & $\begin{array}{c}\text { Cumulative } \\
\text { percent }\end{array}$ \\
\hline \multicolumn{6}{|c|}{ Gender } \\
\hline \multirow[t]{3}{*}{ Valid } & Male & 33 & 33.0 & 33.0 & 33.0 \\
\hline & Female & 67 & 67.0 & 67.0 & 100.0 \\
\hline & Total & 100 & 100.0 & 100.0 & \\
\hline \multicolumn{6}{|c|}{ Marital status } \\
\hline \multirow[t]{3}{*}{ Valid } & Single & 51 & 51.0 & 51.0 & 51.0 \\
\hline & Married & 49 & 49.0 & 49.0 & 100.0 \\
\hline & Total & 100 & 100.0 & 100.0 & \\
\hline \multicolumn{6}{|c|}{ Qualification } \\
\hline \multirow[t]{5}{*}{ Valid } & $\mathrm{BA} / \mathrm{BS}$ & 28 & 28.0 & 28.0 & 28.0 \\
\hline & MA/MS & 56 & 56.0 & 56.0 & 84.0 \\
\hline & MPhil & 14 & 14.0 & 14.0 & 98.0 \\
\hline & $\mathrm{PhD}$ & 2 & 2.0 & 2.0 & 100.0 \\
\hline & Total & 100 & 100.0 & 100.0 & \\
\hline \multicolumn{6}{|c|}{ Language } \\
\hline \multirow[t]{6}{*}{ Valid } & Urdu & 29 & 29.0 & 29.0 & 29.0 \\
\hline & Punjabi & 12 & 12.0 & 12.0 & 41.0 \\
\hline & Balochi & 1 & 1.0 & 1.0 & 42.0 \\
\hline & English & 54 & 54.0 & 54.0 & 96.0 \\
\hline & Other & 4 & 4.0 & 4.0 & 100.0 \\
\hline & Total & 100 & 100.0 & 100.0 & \\
\hline \multicolumn{6}{|l|}{ Age } \\
\hline \multirow[t]{5}{*}{ Valid } & 25 or below & 26 & 26.0 & 26.0 & 26.0 \\
\hline & Above 25 & 41 & 41.0 & 41.0 & 67.0 \\
\hline & $40-45$ & 25 & 25.0 & 25.0 & 92.0 \\
\hline & 50 or above & 8 & 8.0 & 8.0 & 100.0 \\
\hline & Total & 100 & 100.0 & 100.0 & \\
\hline \multicolumn{6}{|c|}{ Income } \\
\hline \multirow[t]{5}{*}{ Valid } & $10,000-25,000$ & 2 & 2.0 & 2.0 & 2.0 \\
\hline & $25000-40,000$ & 38 & 38.0 & 38.0 & 40.0 \\
\hline & $40,000-50,000$ & 17 & 17.0 & 17.0 & 57.0 \\
\hline & 50,000 or above & 43 & 43.0 & 43.0 & 100.0 \\
\hline & Total & 100 & 100.0 & 100.0 & \\
\hline
\end{tabular}




\section{Screening questionnaire}

\section{PBL and 21st century skills}

1. Is there specific coverage of 21st century skills or competencies in the regulations or guidelines/recommendations for compulsory education in your school?

Yes

No

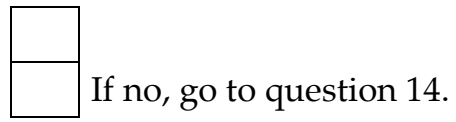

2. Are any of the following skills/competencies covered by these policies?

Creativity

Problem solving

Communication

Information literacy

Media literacy

ICT operations and concepts

Initiative and self-direction

Leadership and responsibility

Critical thinking

Decision making

Collaboration

Research and inquiry

Digital citizenship

Flexibility and adaptability

Productivity

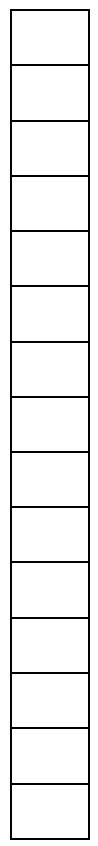

3. What level(s) of education is/are covered by these policies? (Tick all that apply)

Early years

Primary years

Middle years

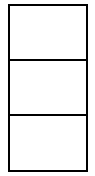

4. When did these regulations/guidelines come into effect?

5. Please briefly explain the policy context and rationale that led to the introduction of these regulations or guidelines regarding 21st century skills and competencies. 
6. Please briefly describe the process through which the specific list of competencies and skills was established.

7. How are these skills taught (e.g., included in the curriculum as a separate subject, taught across subjects)?

8. Are there specific guidelines or regulations regarding the teaching of these skills?

Yes

No

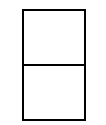

9. If yes, please briefly describe them.

10. Are there regulations or guidelines regarding the assessment or evaluation of these skills?

Yes

No

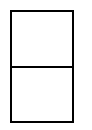

11. If yes, please briefly describe them.

12. Have these regulations or guidelines had an impact on teacher training programs?

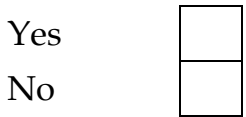

13. If yes, please briefly explain them.

14. Are there currently any discussion or plans in your school to introduce regulations or guidelines on the teaching and evaluation of PBL and 21st century skills in the near future?

Yes

No

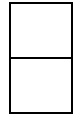

15. If yes, please provide some detail on these discussions or plans. 


\section{Research questionnaire}

The effect of PBL and 21st century skills on student creativity and competitiveness in private schools in Lahore

Please rate the importance of each of the 52 goals listed below to the specific course you have selected. Assess each goal in terms of what you deliberately aim to have your students accomplish, rather than in terms of the goal's general worthiness or overall importance to your institution's mission. There are no "right" or "wrong" answers; only personally accurate or inaccurate ones.

For each goal, circle only one response on the 1 to 5 rating scale. You may find it helpful to quickly read through all 52 goals before rating their relative importance.

In relation to the course you are focusing on, indicate whether each goal rated is:

\begin{tabular}{ll}
\hline (5) Essential & $\begin{array}{l}\text { A goal you always/nearly always try to achieve (76-100\% } \\
\text { of the time) }\end{array}$ \\
(4) Very important & A goal you very often try to achieve (51-75\% of the time) \\
(3) Important & A goal you sometimes try to achieve (26-50\% of the time) \\
(2) Unimportant & A goal you rarely try to achieve (1-25\% of the time) \\
(1) Not applicable & A goal you never try to achieve. \\
\hline
\end{tabular}

\section{Section I}

\section{Demographics}

Survey questionnaire (please encircle your choice of code in the given sections).

1. Gender

\begin{tabular}{ll}
\hline 1 & 2 \\
Male & Female \\
\hline
\end{tabular}

2. Qualification

\begin{tabular}{llll}
\hline 1 & 2 & 3 & 4 \\
Bachelor's degree & Master's degree & MPhil & PhD \\
\hline
\end{tabular}


3. Language

\begin{tabular}{lllllll}
\hline 1 & 2 & 3 & 4 & 5 & 6 & 7 \\
Urdu & Punjabi & Pashto & Sindhi & Balochi & English & Other \\
\hline
\end{tabular}

4. Age

\begin{tabular}{llll}
\hline 1 & 2 & 3 & 4 \\
25 or below & Above 25 & $40-45$ & 50 or above \\
\hline
\end{tabular}

\section{Marital status}

\begin{tabular}{ll}
\hline 1 & 2 \\
Single & Married \\
\hline
\end{tabular}

6. Income

\begin{tabular}{lllll}
\hline 1 & 2 & 3 & 4 & 5 \\
$\begin{array}{l}10,000 \text { or } \\
\text { below }\end{array}$ & $10,000-25,000$ & $25,000-40,000$ & $40,000-50,000$ & $\begin{array}{l}50,000 \text { or } \\
\text { above }\end{array}$ \\
\hline
\end{tabular}

\section{Section II}

Rate the importance of each goal to what you aim to have students accomplish in your course.

\begin{tabular}{|c|c|c|c|c|c|c|}
\hline & & 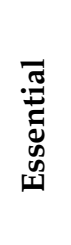 & 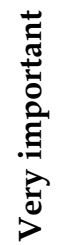 & 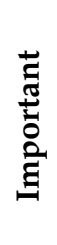 & 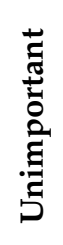 & \begin{tabular}{l}
$\frac{0}{0}$ \\
$\frac{\pi}{0}$ \\
\hdashline$\frac{1}{2}$ \\
$\frac{2}{\pi}$ \\
$\frac{0}{0}$ \\
Z
\end{tabular} \\
\hline 1 & $\begin{array}{l}\text { Develop ability to apply principles and } \\
\text { generalizations already learned to new problems } \\
\text { and situations }\end{array}$ & 5 & 4 & 3 & 2 & 1 \\
\hline 2 & Develop analytic skills & 5 & 4 & 3 & 2 & 1 \\
\hline 3 & Develop problem-solving skills & 5 & 4 & 3 & 2 & 1 \\
\hline 4 & $\begin{array}{l}\text { Develop ability to draw reasonable inferences from } \\
\text { observations }\end{array}$ & 5 & 4 & 3 & 2 & 1 \\
\hline 5 & $\begin{array}{l}\text { Develop ability to synthesize and integrate } \\
\text { information and ideas }\end{array}$ & 5 & 4 & 3 & 2 & 1 \\
\hline 6 & $\begin{array}{l}\text { Develop ability to think holistically to see the whole } \\
\text { as well as the parts }\end{array}$ & 5 & 4 & 3 & 2 & 1 \\
\hline 7 & Develop ability to think creatively & 5 & 4 & 3 & 2 & 1 \\
\hline 8 & Develop ability to distinguish between fact and & 5 & 4 & 3 & 2 & 1 \\
\hline
\end{tabular}




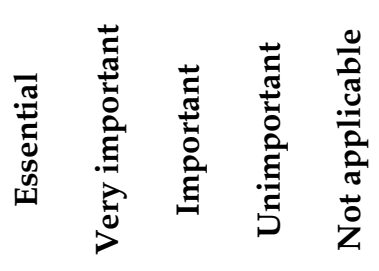

\begin{tabular}{|c|c|c|c|c|c|c|}
\hline & opinion & & & & & \\
\hline 9 & Improve skill at paying attention & 5 & 4 & 3 & 2 & 1 \\
\hline 10 & Develop ability to concentrate & 5 & 4 & 3 & 2 & 1 \\
\hline 11 & Improve memory skills & 5 & 4 & 3 & 2 & 1 \\
\hline 12 & Improve listening skills & 5 & 4 & 3 & 2 & 1 \\
\hline 13 & Improve speaking skills & 5 & 4 & 3 & 2 & 1 \\
\hline 14 & Improve reading skills & 5 & 4 & 3 & 2 & 1 \\
\hline 15 & Improve writing skills & 5 & 4 & 3 & 2 & 1 \\
\hline 16 & $\begin{array}{l}\text { Develop appropriate study skills, strategies, and } \\
\text { habits }\end{array}$ & 5 & 4 & 3 & 2 & 1 \\
\hline 17 & Improve mathematical skills & 5 & 4 & 3 & 2 & 1 \\
\hline 18 & Learn terms and facts of this subject & 5 & 4 & 3 & 2 & 1 \\
\hline 19 & Learn concepts and theories in this subject & 5 & 4 & 3 & 2 & 1 \\
\hline 20 & $\begin{array}{l}\text { Develop skill in using materials, tools, and/or } \\
\text { technology central to this subject }\end{array}$ & 5 & 4 & 3 & 2 & 1 \\
\hline 21 & $\begin{array}{l}\text { Learn to understand perspectives and values of this } \\
\text { subject }\end{array}$ & 5 & 4 & 3 & 2 & 1 \\
\hline 22 & Prepare for transfer or graduate study & 5 & 4 & 3 & 2 & 1 \\
\hline 23 & $\begin{array}{l}\text { Learn techniques and methods used to gain new } \\
\text { knowledge in this subject }\end{array}$ & 5 & 4 & 3 & 2 & 1 \\
\hline 24 & $\begin{array}{l}\text { Learn to evaluate methods and materials in this } \\
\text { subject }\end{array}$ & 5 & 4 & 3 & 2 & 1 \\
\hline 25 & $\begin{array}{l}\text { Learn to appreciate important contributions to this } \\
\text { subject }\end{array}$ & 5 & 4 & 3 & 2 & 1 \\
\hline 26 & $\begin{array}{l}\text { Develop an appreciation of the liberal arts and } \\
\text { sciences }\end{array}$ & 5 & 4 & 3 & 2 & 1 \\
\hline 27 & Develop an openness to new ideas & 5 & 4 & 3 & 2 & 1 \\
\hline 28 & $\begin{array}{l}\text { Develop an informed concern about contemporary } \\
\text { social issues }\end{array}$ & 5 & 4 & 3 & 2 & 1 \\
\hline 29 & $\begin{array}{l}\text { Develop a commitment to exercise the rights and } \\
\text { responsibilities of citizenship }\end{array}$ & 5 & 4 & 3 & 2 & 1 \\
\hline 30 & Develop a lifelong love of learning & 5 & 4 & 3 & 2 & 1 \\
\hline 31 & Develop aesthetic appreciations & 5 & 4 & 3 & 2 & 1 \\
\hline 32 & Develop an informed historical perspective & 5 & 4 & 3 & 2 & 1 \\
\hline 33 & Develop an informed understanding of the role of & 5 & 4 & 3 & 2 & 1 \\
\hline
\end{tabular}




\begin{tabular}{|c|c|c|c|c|c|c|}
\hline & & 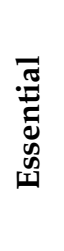 & 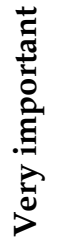 & 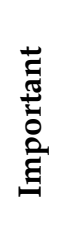 & 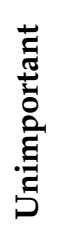 & $\begin{array}{l}\frac{0}{0} \\
\frac{0}{0} \\
\frac{0}{2} \\
\frac{2}{0} \\
\frac{0}{0} \\
z\end{array}$ \\
\hline & science and technology & & & & & \\
\hline 34 & Develop an informed appreciation of other cultures & 5 & 4 & 3 & 2 & 1 \\
\hline 35 & Develop capacity to make informed ethical choices & 5 & 4 & 3 & 2 & 1 \\
\hline 36 & Develop ability to work productively with others & 5 & 4 & 3 & 2 & 1 \\
\hline 37 & Develop management skills & 5 & 4 & 3 & 2 & 1 \\
\hline 38 & Develop leadership skills & 5 & 4 & 3 & 2 & 1 \\
\hline 39 & Develop a commitment to accurate work & 5 & 4 & 3 & 2 & 1 \\
\hline 40 & $\begin{array}{l}\text { Improve ability to follow directions, instructions, } \\
\text { and plans }\end{array}$ & 5 & 4 & 3 & 2 & 1 \\
\hline 41 & Improve ability to organize and use time effectively & 5 & 4 & 3 & 2 & 1 \\
\hline 42 & Develop a commitment to personal achievement & 5 & 4 & 3 & 2 & 1 \\
\hline 43 & Develop ability to perform skillfully & 5 & 4 & 3 & 2 & 1 \\
\hline 44 & $\begin{array}{l}\text { Cultivate a sense of responsibility for one's own } \\
\text { behavior }\end{array}$ & 5 & 4 & 3 & 2 & 1 \\
\hline 45 & Improve self-esteem/self-confidence & 5 & 4 & 3 & 2 & 1 \\
\hline 46 & Develop a commitment to one's own values & 5 & 4 & 3 & 2 & 1 \\
\hline 47 & Develop respect for others & 5 & 4 & 3 & 2 & 1 \\
\hline 48 & Cultivate emotional health and well-being & 5 & 4 & 3 & 2 & 1 \\
\hline 49 & Cultivate physical health and well-being & 5 & 4 & 3 & 2 & 1 \\
\hline 50 & Cultivate an active commitment to honesty & 5 & 4 & 3 & 2 & 1 \\
\hline 51 & Develop capacity to think for oneself & 5 & 4 & 3 & 2 & 1 \\
\hline 52 & Develop capacity to make wise decisions & 5 & 4 & 3 & 2 & 1 \\
\hline
\end{tabular}

